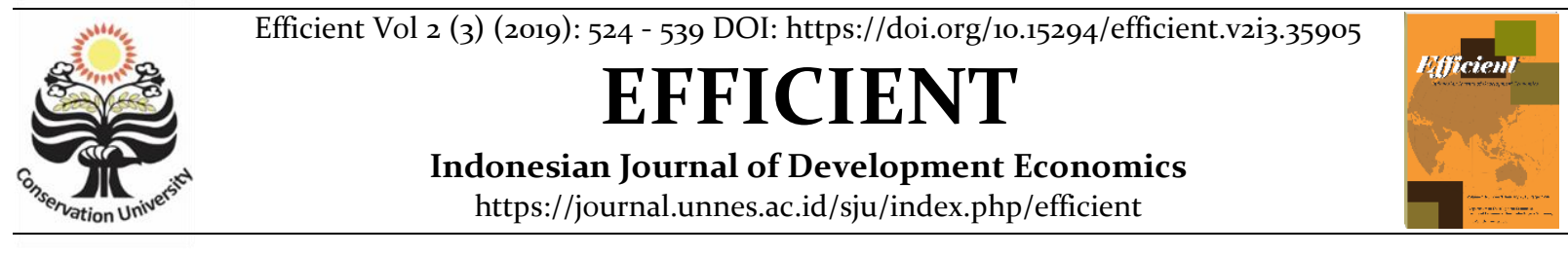

\title{
Determinant Mean Years of Schooling in Central Java
}

\author{
Dina Hernita Lestari ${ }^{1}$, Andryan Setyadharma ${ }^{2}$ \\ Jurusan Ekonomi Pembangunan, Fakultas Ekonomi, Universitas Negeri Semarang \\ Permalink/DOI: https://doi.org/10.15294/efficient.v2i3.35905
}

Received: Juny 2019; Accepted: September 2019; Published: December 2019

\begin{abstract}
The purpose of this research is to determine factors that affect mean years schooling in Central Java between 2014-2017. The data used in this research is panel data. The panel data consists of time series data (2014-2017) and cross section data (35 districts/cities in Central Java). The variables used in this research are dropouts school rate, child labor, BOS fund allocation, per capita income, and poverty rate. The results of this research indicate that: dropouts school rate has insignificant effect on MYS, child labour has a negative and significant effect on MYS, BOS has insignificant effect on MYS, per capita income has a positive and significant effect on MYS, poverty rate has a negative and significant effect on MYS. Based on the results of this research, it is suggested that: (1) The local goverment need to do coordination regulary with related institute; (2) First before other things, finish the poverty problems so the child labor will be decreased; (3) The government needs to maximize work programs other than BOS fund allocation such as the Poor Students Program (BSM) and the Smart Indonesia Card (KIP); (4) The increasement of human welfare will improve the capability to defray education tp the next level; (5) The goverment must maximize more the work program that have been made such as the BSM and KIP programs so it can be reached by children from the poor family.
\end{abstract}

Keywords: School Dropout Rate, Mean Years of Scooling, Poverty, Child Labour

\begin{abstract}
Abstrak
Tujuan dari penelitian ini adalah untuk mengetahui faktor-faktor yang mempengaruhi rata-rata masa sekolah di Jawa Tengah antara 2014-2017. Data yang digunakan dalam penelitian ini adalah data panel. Data panel terdiri dari data deret waktu (2014-2017) dan data penampang (35 kabupaten / kota di Jawa Tengah). Variabel yang digunakan dalam penelitian ini adalah angka putus sekolah, pekerja anak, alokasi dana BOS, pendapatan per kapita, dan tingkat kemiskinan. Hasil penelitian ini menunjukkan bahwa: tingkat putus sekolah berpengaruh tidak signifikan terhadap MYS, pekerja anak memiliki efek negatif dan signifikan terhadap MYS, BOS memiliki efek tidak signifikan pada MYS, pendapatan per kapita memiliki efek positif dan signifikan terhadap MYS, tingkat kemiskinan memiliki efek negatif dan signifikan pada MYS. Berdasarkan hasil penelitian ini, disarankan agar: (1) Pemerintah daerah perlu melakukan koordinasi secara teratur dengan lembaga terkait; (2) Pertama sebelum hal-hal lain, selesaikan masalah kemiskinan sehingga pekerja anak akan berkurang; (3) Pemerintah perlu memaksimalkan program kerja selain alokasi dana BOS seperti Program Siswa Miskin (BSM) dan Kartu Indonesia Pintar (KIP); (4) Peningkatan kesejahteraan manusia akan meningkatkan kemampuan untuk membiayai pendidikan ke tingkat berikutnya; (5) Pemerintah harus memaksimalkan lebih banyak program kerja yang telah dibuat seperti program BSM dan KIP sehingga dapat dijangkau oleh anak-anak dari keluarga miskin.
\end{abstract}

\section{Kunci: Tingkat Putus Sekolah, Rata-rata Tahun Pencurangan, Kemiskinan, Pekerja Anak}

How to Cite: Lestari, D., \& Setyadharma, A. (2019). Determinant Mean Years of Schooling in Central Java. Efficient: Indonesian Journal of Development Economics, 2(3), 524-539. https://doi.org/10.15294/efficient.v2i3.35905

(C) 2019 Semarang State University. All rights reserved

\footnotetext{
Alamat Korespondensi :

Alamat: Gedung L2 Lantai 2 FE Unnes

ISSN 2655-6197

Kampus Sekaran, Gunungpati, Semarang, 50229

E-mail : efficientjournal@gmail.com
} 


\section{INTRODUCTION}

Human development is one indicator of the progress of a country. According to Widodo, Waridin, \& Kodoatie (2011), a country is said to be developed not only in terms of Gross Domestic Income (GDP) but also includes aspects of life expectancy and the education of its people. This can be interpreted that human development is one indicator for an area in development, where the development of an area cannot be said to be successful if it only looks at the amount of Gross Regional Domestic Product (GRDP) without increasing its human development.

To see the success of development to be more accurate, two indicators are needed, namely economic indicators and social indicators. In line with this, since 1990 the United Nations through the United National Development Program (UNDP) developed an index that is now known as the Human
Development Index (HDI) or Human Development Index (HDI) to analyze the comparison of socioeconomic development in developing and developed countries (Kuncoro, 2003: 3).

HDI is one indicator used as a measurement in human development, especially in measuring the physical quality of the population in an area. Therefore, HDI is used as a standard for the success of comprehensive and adequate development policies. HDI is composed of 3 main components namely health, education and economy. The health index is illustrated by life expectancy, the education index is represented by mean years of schooling and length of schooling expectations, and the purchasing power index is illustrated by adjusted real per capita expenditure (Kuncoro, 2003:3).

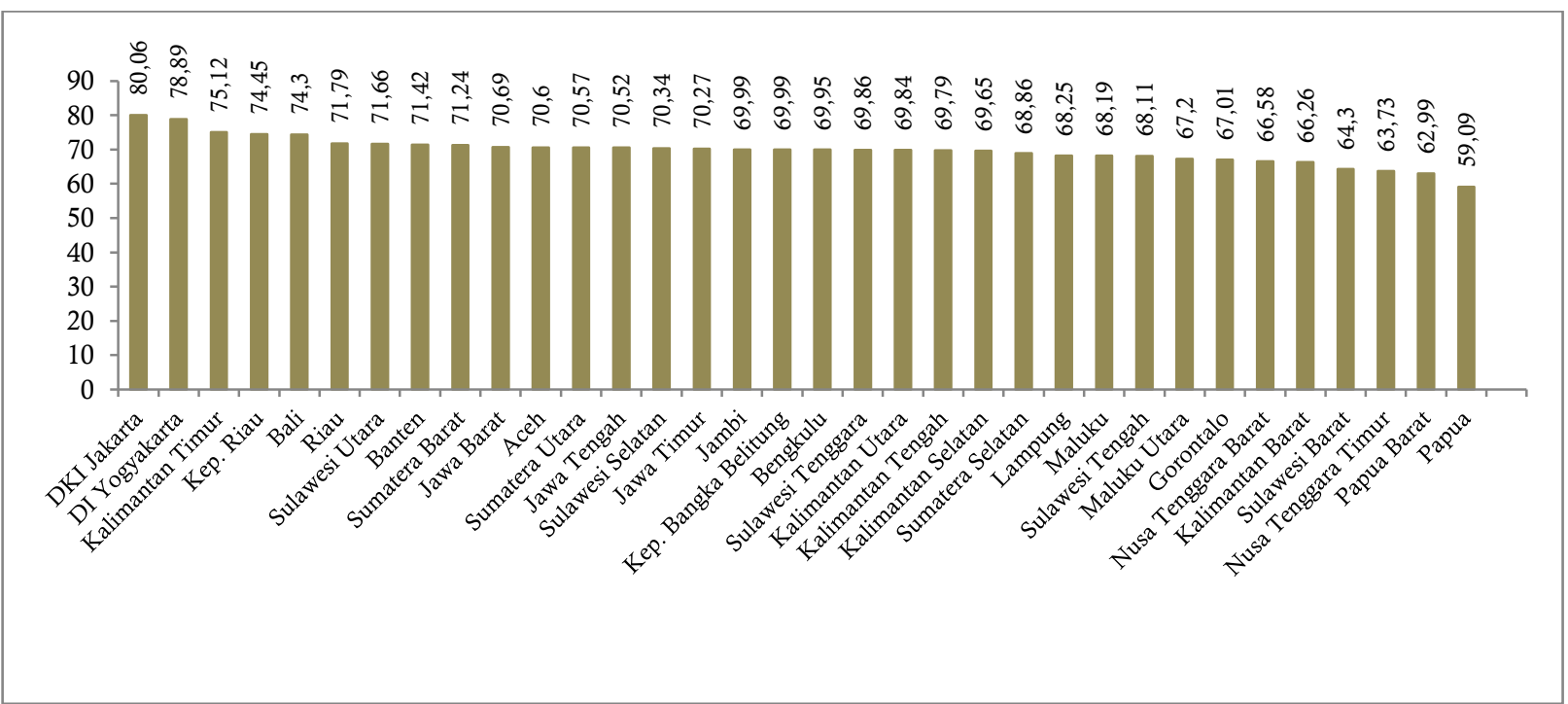

Figure 1. HDI Province in Indonesia in 2017

Source : Central Bureau of Statistics (2018) 
Based on Figure 1 shows that the provincial HDI in Indonesia in 2017. DKI Jakarta Province ranks first with the highest HDI. While the province with the lowest HDI is Papua. The provinces of Java are provinces with a high Human Development Index (HDI). Even DKI Jakarta and DI Yogyakarta are ranked first and second HDI nationally. In other words, each component has a contribution in forming the HDI. Java Island as an economic center has a higher quality of human resources compared to Islands outside Java.

Nevertheless, Central Java as an economic center on the island of Java still has problems in the field of education. The low education index in Central Java is mean years of schooling. Based on table 1, mean years of schooling in Central Java in 2017 is only 7.27 years, while mean years of schooling in Java is 8.59 years and mean years of national school is 8.11 years. The mean year of schooling in Central Java in 2017 is below mean years of schooling in Java and nationally. Even when compared to islands outside Java, Central Java is in the zoth position under provinces outside of Java Island such as Kalimantan Island, Sumatra Island and Sulawesi Island.

The mean years of schooling of the population of Central Java reach 7.27 years. This figure shows that on average the education level has only reached junior high school (class VII). This is reinforced by the large percentage of the population in Central Java who only completed their highest education up to the elementary school level, meaning that the government's attention to improve the quality of human resources by compulsory education for up to 9 years or junior high school level has not been reached. This condition causes education in Central Java has not yet succeeded in achieving the Program Wajib Belajar Sembilan Tahun.

Table 1. Mean Years of Schooling by Province in Indonesia in 2017

\begin{tabular}{|c|c|}
\hline Province & Mean Years of Schooling \\
\hline DKI Jakarta & 11,02 \\
\hline Kep. Riau & 9,79 \\
\hline Maluku & 9,38 \\
\hline East Kalimantan & 9,36 \\
\hline North Sumatra & 9,25 \\
\hline In Yogyakarta & 9,19 \\
\hline North Sulawesi & 9,14 \\
\hline Aceh & 8,98 \\
\hline Riau & 8,76 \\
\hline West Sumatra & 8,72 \\
\hline North Kalimantan & 8,62 \\
\hline North Maluku & 8,61 \\
\hline Bali & 8,55 \\
\hline Banten & 8,53 \\
\hline Bengkulu & 8,47 \\
\hline Southeast Sulawesi & 8,46 \\
\hline Central Kalimantan & 8,29 \\
\hline Central Sulawesi & 8,29 \\
\hline Jambi & 8,15 \\
\hline West Java & 8,14 \\
\hline South Sumatra & 7,99 \\
\hline South Kalimantan & 7,99 \\
\hline South Sulawesi & 7,95 \\
\hline Lampung & 7,79 \\
\hline $\begin{array}{ll}\text { Kep. } & \text { Bangka } \\
\text { Belitung } & \end{array}$ & 7,78 \\
\hline East Java & 7,34 \\
\hline West Sulawesi & 7,31 \\
\hline Gorontalo & 7,28 \\
\hline Central Java & 7,27 \\
\hline East Nusa Tenggara & 7,15 \\
\hline West Papua & 7,15 \\
\hline West Kalimantan & 7,05 \\
\hline $\begin{array}{ll}\text { West } & \text { Nusa } \\
\text { Tenggara } & \end{array}$ & 6,9 \\
\hline Papua & 6,27 \\
\hline Indonesia & 8,1 \\
\hline
\end{tabular}

Source: Central Bureau of Statistics (2018) 
The level of education is one measure for the quality of the population. The higher the level of education completed the better the quality of human resources in the region. Completion of school is defined as a level of education that has been successfully completed by someone with proof of a diploma or letter of completion. But if you use a measure according to the highest level is the highest level or class that has been taken by someone.

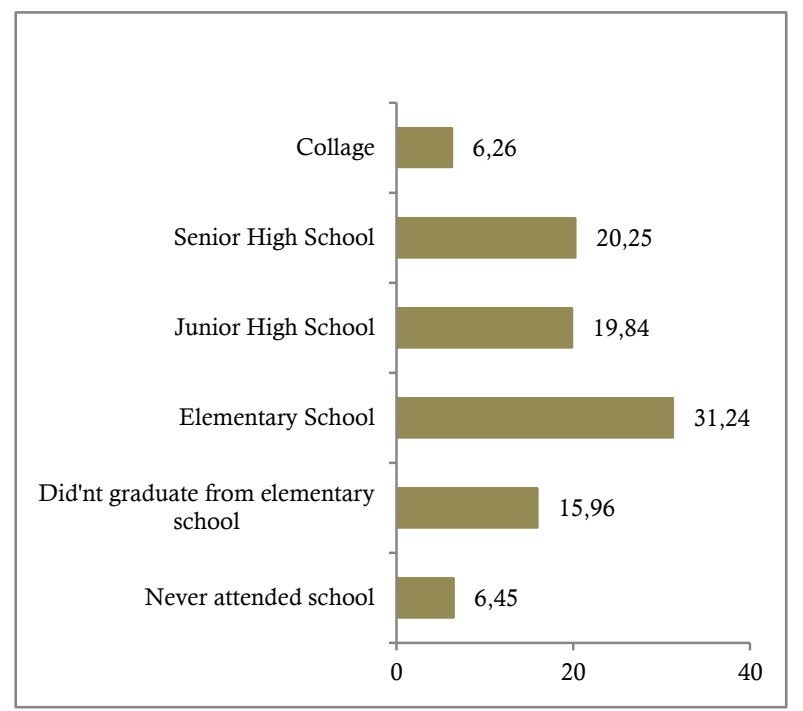

Figure 2. Percentage of Population by Highest Level of Education in Central Java in 2017 (\%) Source: Central Statistics Agency for Central Java Province. (2017).

On Figure 2 can be seen that the higher the level of education, the smaller the number of people taking education. In 2017, the percentage of the highest level of education was the population who graduated from elementary school by $31.24 \%$, then dropped at the level of junior high school to $19.84 \%$. This shows the existence of students dropping out of school which caused a decrease in the number of junior high school graduates. Also, there are still $6.45 \%$ of the population 15 years and over who have never attended school and as much as $15.96 \%$ have attended elementary school but did not graduate. Also, it can be said that the number of continuing school to a higher level of education in Central Java is still low.

To realize the Program Wajib Belajar Sembilan Tahun, one of the programs that are expected to play a major role in accelerating the completion of the quality of the Program Wajib Belajar Sembilan Tahun is BOS funds program. The program began in July 2005 and has a significant impact on the Program Wajib Belajar Sembilan Tahun (Dong, 2014). BOS funds program is given to elementary, junior and senior high schools with the aim of freeing up the cost of education for students who cannot afford it and easing the burden on other students, in order to obtain higher quality basic education services to graduate in order to achieve the Program Wajib Belajar Sembilan Tahun (Kharisma, 2013).

In line with BOS program's goal, which is to free up the cost of education for poor students in the context of completing the nineyear compulsory education, BOS funds must be disbursed more to provinces that have poor residents. The largest number of poor people in Java are East Java at 4,511.14 thousand people, followed by Central Java at 4,324,105 thousand people. While the poorest population is at least in DI Yogyakarta with 35,694 thousand inhabitants.

From Figure 3, it can be seen that Central Java is the province with the second largest number of poor people on Java, but the allocation of BOS funds distributed is only 578.986 million rupiahs. This shows the distribution of BOS fund allocations for the poor population in Central 
Java is still lacking and not following the objectives of BOS which are in favor of the continuity of the education of poor students.

Poverty is influenced by per capita income. Per capita income in an area can be used as a parameter of community welfare in the area. With increasing per capita income, poverty will decrease, because the welfare of the community will increase and more needs can be met.

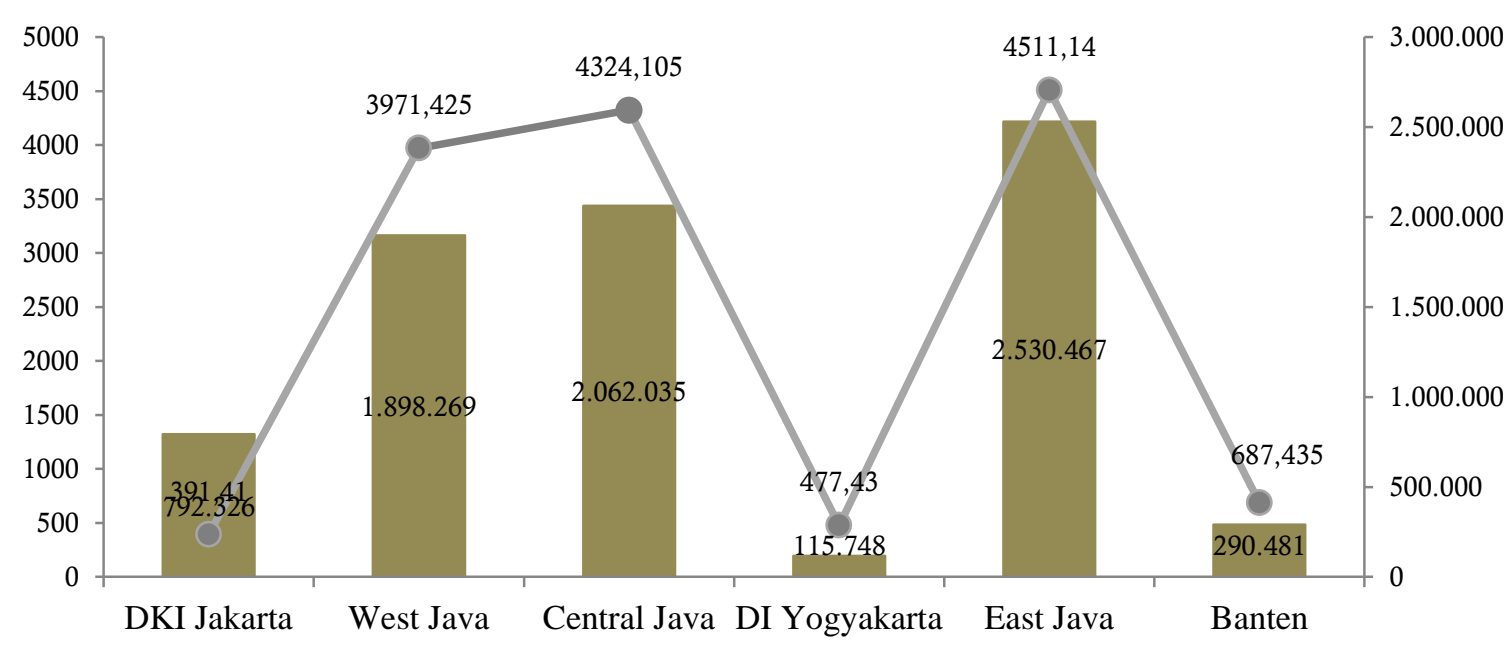

Allocation BOS funds (million rupiahs)

- Poor Population (thousand people)

Figure 3. BOS Fund Allocation and Number of Poor Residents in 2017

Sources: bos.kemdikbud.go.id dan Central Bureau of Statistics (2018)

According to Keynes's theory, the size of the consumption pattern of society is influenced by the size of the income itself. The pattern of community consumption depends on the source of household income, the higher the household income, the more needs will be met. Thus, per capita income can reflect the ability of the community to finance education so that community education will continue to increase when their income rises.

Figure 4 shows the development of per capita income in Central Java which continued to increase from 2014 to 2017. In 2017 per capita income in Central Java reached. 26.097.670 rupiahs. According to Todaro \& Smith (2011), education level and income level have a positive correlation. The higher a person's income, the higher the level of education he completes. The cost of education is still a barrier for low-income families to pay for their children's education.

Various programs in Program Wajib Belajar Sembilan Tahun have been implemented, but children who have dropped out of school are still found. According to Choiriyah, Linuwih, \& Salamah (1990), there are several reasons for children dropping out of school, namely: the condition of the child 
itself, his family background, the influence of parents, culture, and environment. However, most of the reasons that cause school-age children to quit school are due to economic factors, because they cannot afford to pay school fees and other costs, as well as their parents, need them to help work.

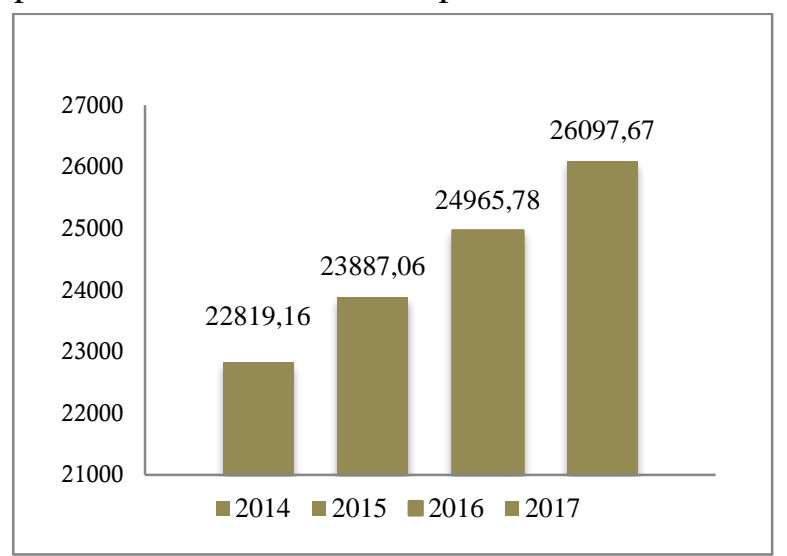

Figure 4. Per Capita Income in Central Java in 2014-2017.

Source: Central Statistics Agency for Central Java Province. (2017).
Table 2 shows the number of students dropping out of school every year experiencing a downward trend from 2014 to 2016 and increasing in 2017. The highest number of dropout students in Java is West Java at 122,537, East Java at 61,340 and Central Java at 46,969 children. The number of students dropping out of school shows that human development is still lagging, especially in the field of education. Besides, the large number of students dropping out of school also causes children to not have activities so they tend to choose to work to help their parents make money. Although, Central Java occupies the third position on the island of Java with the highest number of students dropping out of school, the result of dropout is that the highest number of child laborers in Central Java is in Java.

Table 2. Number of Students Dropping Out of School in Java Island Year 4014-2017

\begin{tabular}{cccccc}
\hline Province & 2014 & 2015 & 2016 & 2017 & Total \\
\hline DKI Jakarta & 10182 & 4148 & 2668 & 3120 & 20.118 \\
West Java & 62425 & 23439 & 18958 & 17715 & 122.537 \\
Banten & 14311 & 6301 & 4630 & 4890 & 30.132 \\
Central Java & 19694 & 10084 & 8496 & 8695 & 46.969 \\
Yogyakarta & 1656 & 802 & 669 & 713 & 3.840 \\
East Java & 25317 & 12705 & 9956 & 13362 & 61.340 \\
\hline
\end{tabular}

Source : Center for Education and Culture Statistics (2018)

Table 3 shows that the number of child workers in Central Java was the most compared to other provinces in 2017. The number of child workers in Central Java was 382.8 thousand children with a ratio of boys working more than girls namely $\mathbf{2 2 2 . 2}$ thousand and 1606 thousand.

According to Subri (2003), there are three forms of work involvement of children, namely: (1) children who work to help their parents, (2) children who work with apprenticeship status, where apprenticeship is one way to be able to master the skills needed. The internship job market is often seen as a process of socialization based on a method or mechanism of "learning by doing" (learning by doing). Formal internships can be done both formally and informally. Formally, an 
apprenticeship can be done by learning while working for an expert and this type of apprenticeship is used to get cheap labor. Whereas informally, the apprenticeship can be done by learning to their own parents, (3) children who work as laborers/employees. Where child labor is tied to work relations, between laborers and employers, and receives wages in the form of money. If viewed from the status of work, then the main status of child labor can be divided into five categories, namely independent businesses, businessesassisted by household members or temporary workers, businesses assisted by permanent workers, permanent employees and family workers / unpaid.

Table 3. Number of Child Laborers in Java 2017

\begin{tabular}{llll}
\hline \multirow{2}{*}{ Province } & \multicolumn{3}{c}{ Child Laborers (ooo) } \\
\cline { 2 - 4 } & $\mathrm{L}$ & $\mathrm{P}$ & Total \\
\hline DKI Jakarta & 31,8 & 61,8 & 93,6 \\
West Java & 189,1 & 165,2 & 354,3 \\
Banten & 44 & 49,4 & 93,4 \\
Central Java & $\mathbf{2 2 2 , 2}$ & 160,6 & 382,8 \\
DI Yogyakarta & 18,4 & 18,6 & 37 \\
East Java & 201,9 & 121,5 & 323,4 \\
\hline
\end{tabular}

Source: Central Bureau of Statistics (2018)

According to Zahra (2016), children who work tend to have low educational attainments with household welfare levels that are also low compared to children who only attend school. For children who have dropped out of school, child labor is the easiest alternative compared to other jobs such as factory workers who need a diploma, at least a junior high or high school level.

Based on this background, several research questions can be formulated as follows: 1) What is the effect of school dropout rate affect the mean years of schooling in regencies and cities in Central Java? 2) What is the effect of child labor on the mean years of schooling in regencies and cities in Central Java? 3) What is the effect of the allocation of BOS funds on the mean years of schooling in regencies and cities in Central Java? 4) What is the effect of per capita income on the mean years of schooling in regencies and cities in Central Java? 5) What is the effect of poverty rate on the mean years of schooling in regencies and cities in Central Java?

The objectives of the study are as follows: 1) Knowing the school dropout rate from mean years of schooling in regencies and cities in Central Java; 2) Knowing the child labor on mean years of schooling in regencies and cities in Central Java; 3) Knowing the allocation of BOS funds for secondary schools in regencies and cities in Central Java; 4) Knowing the per capita income per to mean years of schooling in regencies and cities in Central Java; 5) Knowing the poverty rate in school length in regencies and cities in Central Java.

According to Todaro \& Smith (2011), there is something positive between the level 
of education and the level of income. A person's education level is still an income level. The higher a person's income, the higher the level of education he completes.

Per capita income is an indicator of community welfare. This is due to economic reasons because a higher level of education will require higher costs (Suryadarma, Suryahadi, \& Sumarto, 2006).

Research Granado, Fengler, Ragatz, \& Yavuz (2007) said that higher education requires higher costs as well so that the poor who do not have enough economic capacity to pay for their children's schooling cannot send their children to higher levels of education. Regions with low poverty rates can achieve a high average length of schooling.

Research Suryadarma et al., (2006) states the low length of schooling in Indonesia is caused by a large number of students dropping out of school. Termination of students from the school causes these students to not be able to continue their education to the next level so that the length of schooling taken by the population has not reached the government's target.

The average level of education taken by residents in an area can be seen by using the average number of years of schooling. Also, mean years of schooling is used to look at school dropout rates. For example, when the government wants to reduce the number of dropouts, one of the efforts is to increase the mean years of schooling both through government policies and programs.

Research Granado et al., (2007)states that there is a trade-off between work and school. This is because going to school requires money, while work can generate money to help support his family's income. Most of them prefer to work rather than continue school.

According to ILO (2009), children who have decided to enter the workforce will have low motivation to continue school. A child who works will have an impact on not fulfilling their right to get proper education and other rights that should be obtained by children their age. Child laborers are forced to work or choose to work because of the economic conditions of their families. This will affect the development of these children, can cause them to a school dropout rate of school and the learning process at school becomes ineffective.

Poverty is another reason that causes children to work. This becomes an obstacle in achieving adequate education because children will leave school at an early age due to poverty. The work situation is a necessity/need, but in the end, they lose education. Education is also seen as not providing guarantees in providing better life opportunities. This is because some assume that working at an early age can make it easier for children to get work opportunities in adulthood.

According to Iskandar \& Aziz (2013), children who start working in youth are more vulnerable to the risk of worker exploitation. The form and benefits of the work itself are sometimes not on target, in the sense that the level of difficulty of work with physical conditions is not balanced, which sometimes unknowingly closes access for children to enjoy education and directly affect children's psychologists. Thus, child labor is work that keeps children away from school.

One of them is through BOS funds and Program Wajib Belajar Sembilan Tahun which means free education from elementary to 
junior high levels from 2008. Then the Universal Education program is the government's effort to provide education to the secondary level in 2013.

Research Granado et al., (2007) said that the BOS funding program could encourage more children from poor households to attend school. This BOS fund reduces barriers to poor students to attend school by helping poor students to access appropriate educational services and prevent dropping out of school.

With the BOS funds, all elementary, junior and senior high school students are exempt from fees for school operations. Funding for all activities in schools related to the learning process and supporting them can be met to ease the burden of school operating costs for students at school.

\section{METHOD}

This research uses quantitative research methods using panel data. Panel data is a combination of individual data (cross section) and time series data. The number of observations in this study was 140 , which consisted of the 2014-2017 time series data, and cross data of 35 regencies/cities in Central Java Province. The variables used in this study are divided into two parts, namely the independent or independent variable and the dependent or dependent variable. The dependent variable in this study is mean years of schooling. The independent variables in this study include the following:

The school dropout rate in this study is the proportion of children according to the school age group who are no longer in school or who have not completed primary, junior and senior high school education in 35 regencies and cities in Central Java from 20142017 in percent units.

Child laborers in this study are workers under the age of the labor force who work under the age of 15 in 35 regencies and cities in Central Java from 2014-2017 in child units.

BOS funds in this study are BOS distribution funds for elementary, junior high, and senior high schools consisting of 4 quarters of the year in 35 regencies and cities in Central Java from 2014-2017 in rupiah units.

Per capita income in this study is the result of the distribution of regencies and cities GRDP in Central Java with the population of regencies and cities in Central Java. GRDP in this study uses GRDP based on constant prices in 2010. The data used in this study are per capita income data in 35 regencies and cities in Central Java from 2014-2017 in rupiah units.

Poverty rate in this study is the percentage of the population below the poverty line in 35 regencies and cities in Central Java from 2014-2017 in percent units.

The models used in this study are:

RLSit $=\beta_{o}+\beta_{1}$ APtS it $+\beta_{2}$ PA it $+\beta_{3}$ BOSit $+\beta_{4}$
PP it $+\beta_{5}$ MIS it + e it $\ldots \ldots \ldots \ldots \ldots \ldots \ldots \ldots \ldots \ldots \ldots \ldots \ldots . . .1(1)$

Information:

RLS Mean years of school

APtS School dropout rate

PA Child labor

BOS BOS Funds

PP Per Capita Income

MIS Poverty rate

B Regression coefficient

i Cross section data of 35 regency/city

$(i=1,2,3, \ldots, 35)$

t Time series data of 2014-2017

e Error 


\section{RESULTS AND DISCUSSION}

In this study there are three panel data estimation models namely the common effect model, fixed effect model and random effect model. The results of the three panel data estimation models areas follows:

Table 4. Panel Data Estimation Result

\begin{tabular}{|c|c|c|c|c|}
\hline \multirow{2}{*}{ No } & \multirow{2}{*}{ Variable } & \multicolumn{3}{|c|}{ Model } \\
\hline & & Common & Fixed & Random \\
\hline \multirow[t]{3}{*}{1} & Constanta & 7,913576 & 6,832883 & 7,339364 \\
\hline & Std.Error & 0,35347 & 0,911869 & 0,547374 \\
\hline & Prob & 0,000 & 0,0000 & 0,0000 \\
\hline \multirow[t]{3}{*}{2} & School dropout rate & $-0,084165$ & $-0,002999$ & $-0,003292$ \\
\hline & Std.Error & 0,037669 & 0,007149 & 0,007045 \\
\hline & Prob & 0,0271 & o,6757 & 0,641 \\
\hline \multirow[t]{3}{*}{3} & Child Labor & $-0,000375$ & $-0,000198$ & $-0,000225$ \\
\hline & Std.Error & o,0000997 & 0,0000864 & o,0000777 \\
\hline & Prob & 0,0003 & 0,024 & 0,0044 \\
\hline \multirow[t]{3}{*}{4} & BOS Funds & 0,00000000000310 & 0,000000000000459 & 0,000ooooooooog12 \\
\hline & Std.Error & 0,0000000000023 & 0,000000000000735 & o,000000000000645 \\
\hline & Prob & 0,9893 & 0,5334 & 0,1594 \\
\hline \multirow[t]{3}{*}{5} & Per Capita Income & 0,0000000332 & 0,0000000588 & 0,0000000448 \\
\hline & Std.Error & 0,00000000521 & o,0000000117 & o,00000000758 \\
\hline & Prob & 0,0000 & 0,0000 & 0,0000 \\
\hline \multirow[t]{3}{*}{6} & Poverty Rate & $-0,061663$ & $-0,058156$ & $-0,069514$ \\
\hline & Std.Error & 0,022129 & 0,058444 & 0,033038 \\
\hline & Prob & 0,0061 & 0,3221 & 0,0372 \\
\hline 7 & R-squared & 0,589709 & 0,991502 & 0,500024 \\
\hline 8 & Adjusted R-squared & 0,5744 & 0,988188 & 0,481368 \\
\hline 9 & F-Statistik & 0,0000 & 0,0000 & 0,0000 \\
\hline 10 & Prob(F-Statistik) & 0,142135 & 1,629603 & 0,032326 \\
\hline
\end{tabular}

Significance $\alpha=5 \%$

Source: Data processed Eviews.o9 (2019)

To find out the right model as a tool to analyze research data, a model selection test was conducted. There are two stages of statistical testing conducted in this study. The first stage is the likelihood ratio test to determine the best model between common effect model and fixed effect model. Then the second stage is the thirst test to determine the best model between the fixed effect model and the random effect model.

\section{Redundant Fixed Effect-Likelihood Ratio}

In this test we get cross-section $\mathrm{F}$ of 137.552817 with a probability of 0.0000 and significant to $\alpha=5 \%(0,05)$. So it can be 
decided that the selected model is fixed effect model, because the probability value of crosssection $\mathrm{F}$ is $0.0000<0.05$.

\section{Correlated Random Effect-Hausman Test}

In this test we get the random crosssection value of 9.368035 with probability of 0.0953 and not significant to $\alpha=5 \%(0,05)$. So it can be decided that the selected model is random effect model, because the probability value of cross- section $\mathrm{F}$ is $0,0953>0,05$.

Based on the regression results obtained R2 with the random effect model approach of 0.500657 . This means that the ability of the model variation of school dropout rate, child labor, BOS, per capita income and poverty income can explain the mean years of schooling in Central Java in 2014-2017 that is equal to $50 \%$. While the remaining $50 \%$ is explained by other variables outside the model. Based on regression result by using random effect model obtained an F-count value equal to 26.83581 using $\alpha=5 \%$. The calculation of the F-table is the degree of freedom for numerator $(\mathrm{dfn})=4(\mathrm{k}-1=5-1)$ and the degree of freedom of denominator $(\mathrm{dfd})=$ 134 (nk = 140-5), then the F-table of 2.214 is obtained. That means the F-count $>$ F-table (26.83581> 2.44) and the statistical $F$ probability of 0.00000 is significant at $\alpha=5 \%$. It can be concluded that dropout school rate, child labor, BOS fund, per capita income and poverty rate together affect the mean years of schooling in the regencies and cities in Central Java in 2014-2017.

T-test is done by comparing the t-count value with the $t$-table value. If the value of $t$ statistik $>\mathrm{t}$-table, then Ho is rejected and $\mathrm{Ha}$ is accepted, which means that the independent variable partially has a significant effect on the dependent variable. Where the value is obtained from $\alpha$ : df $(n-k)$. Value of $t$ table $=(\alpha$ $=0.05: \mathrm{df}=135)=1.65622$. The following are the results of the t-statistic calculation:

Table 5. Result of T-Statistics Test

\begin{tabular}{lcccc}
\hline Variable & t-statistic & Probability & t-table & Conclusion \\
\hline School dropout rate & $-0,46733$ & 0,4952 & 1,65622 & Unsignificance \\
Child Labor & $-2,89357$ & 0,0026 & 1,65622 & Significance \\
Bos Funds & 1,414805 & 0,1338 & 1,65622 & Unsignificance \\
Per Capita Income & 5,908815 & 0,0000 & 1,65622 & Significance \\
Poverty Rate & $-2,10408$ & 0,0356 & 1,65622 & Significance \\
\hline
\end{tabular}

Source: Data processed Eviews 9.o (2019) 
Based on regression result with random effect model method, obtained regression coefficient value for each research variable with formulation as follows :

$\mathrm{RLS}$ it $=7,363213-0,004871 \mathrm{APtSit}-$ o,000240PAit + o,000o000000026BOS it + o,0000000449PPit - o,070883MIS it + e it

\section{Result of Hypothesis Test}

Based on the estimation results show that the school dropout rate has no effect on mean years of school at the $5 \%$ level in the Regencies and cities of Central Java Province. The regression coefficient value of the variable school dropout rate is 0,003292 . This means the school dropout rate has not fully influenced mean years of schooling in the Regencies and cities of Central Java Province.

The results of this study are not in line with research Suryadarma et al., (2006). The study states the low length of schooling in Indonesia is caused by the large number of students dropping out of school. Termination of students from school causes these students to not be able to continue their education or study program to the next level.

According to Gunawan (2000:71), dropping out of school is a predicate given to former students who are unable to complete an education level, so they cannot continue their studies to the next level of education. This means dropping out of school is directed at someone who has attended school but stopped attending school. If the school dropout rate is low, the number of continuing education to the next level increases.

The number of children dropping out of school has a low graph, starting from elementary to junior high school. The school dropout rate at the elementary level tends to decrease significantly in 2014-2017. In 2014, the number of students in elementary school was 2,941,627 children, only around $0.32 \%$ or 9,419 children who dropped out of school. This number dropped dramatically in 2017, there were around 2,238 children or $0.08 \%$ of the total number of elementary school students 2,857,363 children.

In addition, the school dropout rate at the junior secondary level has also decreased. The number of junior high school students in Central Java in 2014 was 1,219,304 students, there were around 6,194 students or $0.51 \%$ of students who dropped out of school. In 2017 , there were around 4,891 children or $0.40 \%$ of the total number of SMP students 1,194,666 children. As for the high school level, there are around 402804 children. The school dropout rate is 1,566 children or $0.40 \%$. This means that as many as 401,238 high school students attend school. Although Central Java's school dropout rate is ranked 3 rd from the provinces in Java, but the rate of continuing school is also high so that the number of students dropping out has not fully influenced mean years of schooling in Central Java.

Based on the estimation results show that child labor has a negative an significant effect on mean years of school at a significant level of $5 \%$ in the Regencies and cities of Central Java Province. The regression coefficient value of the children's work variables is 0,000225 . This means that if child labor increases by 1 child, mean years of schooling will decrease by 0,000225 years, assuming ceteris paribus.

According to Todaro \& Smith (2006), parents in developing countries still view children as workers who can help the lives of 
parents. Child labor is needed to supplement income. If the child attends school, the family will lose some of the income that might be earned. Parents think the opportunity cost of a child who works is more profitable than going to school. This is also in line with the study of Granado et al., (2007) which concluded a trade-off between work and school. This is due to school costs while working to make money to help the family income. Most of them prefer to work rather than continue school.

According to Vandenberg (2009), children who have decided to work will have low motivation to continue school. A child who works has an impact on not fulfilling their right to obtain a proper education and other rights that should be obtained by children their age. Child laborers are forced to work or choose to work because of the economic conditions of their families. This will affect the development of these children and can cause them to school dropout rate of school and the learning process at school becomes ineffective.

The case of child labor makes participation in the education system difficult were hours spent at work begin to compete with school activities and make them lose focus on their schoolwork. One can argue that children's school attendance will be affected by work depending on the type of work activity and the hours spent working.

According to Subri (2003), the emergence of child labor is a socio-economic problem which is quite alarming, because ideally at the age of under 15 they should only gain knowledge and not be burdened by making a living. But on the contrary many children who are interrupted by the school even drop out of school because of work.
Work activities for children can hamper the process and achievement of learning outcomes in schools, and ultimately will have an impact on the sustainability of their schools. Based on the results of the study revealed that working children tend to get low achievement and can reduce their chances of continuing school (Khanam, 2008). However, because of the many problems that must be faced so that not a few child workers who prefer to work and leave school.

Education can help change and improve children's lives and futures. Poverty is another reason that causes children to work. This becomes an obstacle in achieving adequate education because children will leave school at an early age due to poverty. The work situation is a necessity/need, but in the end, they lose education. Education is also seen as not providing guarantees in providing better life opportunities. This is because some assume that working at an early age can make it easier for children to get work opportunities in adulthood.

Based on the estimation results show that the allocation of BOS funds does not affect mean years of school at the $5 \%$ level in the regencies and cities of Central Java Province. The regression coefficient value of the BOS fund allocation variable is o,oooooooooooooog12. This means that the allocation of BOS funds has not yet fully influenced mean years of schooling in Central Java Province .

The study is not in accordance with Granado et al., (2007) which says that the BOS funding program can encourage more children from poor households to attend school. BOS funds reduce the problem of poor students 
going to school by helping poor students get access to proper education services and prevent dropping out of school.

BOS funds are expected to be able to reduce the cost of schooling for the community, especially the poor so that the number of student participation increases. But in reality BOS funds have not had a significant impact on mean years of schooling in Central Java. This is seen from many children who cannot go to school, school dropout rate of school and cannot continue their education to the next level of education. One reason for this is the difficulty of parents / families in meeting educational needs that are not covered by BOS funds. The BOS Fund has been launched by the government to free education costs, but it has not yet supported the operational costs of school children such as books, uniforms, and transportation costs. BOS funds have not been able to accommodate the interests of the school because there are still levies imposed on parents who are explicit from the school concerned.

Based on the estimation results show that per capita income has a positive and significant effect on mean years of school at the $5 \%$ level in the Regencies and cities of Central Java Province. The regression coefficient value of the variable income per capita is o,0000000448. It means that if per capita income rises by 1 million, mean years of schooling will increase by 0,0448 years with the assumption of ceteris paribus.

According to Todaro \& Smith (2011), there is a positive correlation between education level and income level. The higher a person's income, the higher the level of education he completes. This supports the research of Suryadarma et al., (2006) which says that per capita income as an indicator for community welfare significantly influences school participation. This is due to economic reasons because the higher the level of education will require higher costs. This is also consistent with Hartoyo \& Anggraeni (2015) research which says that the higher the income per capita of the community, the more they can send their children to the elementary and junior high school levels. This means an increase in per capita income will increase mean years of schooling.

An increase in the income of the people of Central Java every year shows that the level of welfare of the people of Central Java has increased. Increased income will encourage individuals or groups to improve their welfare, thus encouraging someone to meet needs such as education.

According to Todaro and Smith (2006), there are two education costs, namely individual direct education costs and indirect education costs. These individual direct education costs are directly related to the income per capita of the community. Individual direct education costs are costs borne by students and their families to finance education, while indirect costs are the opportunity costs incurred for choosing to go to school, not other alternatives, for example, work. Individual direct education costs include money to pay school fees, buy books, buy uniforms, pay transportation fees to school, and others. The level of education is directly proportional to the number of direct education costs, meaning that the higher the level of education a child receives, the greater the individual direct education costs borne by the student's parents. For low-income residents, 
the direct costs of providing primary education alone have imposed them and consumed a significant amount of their real income. While indirect costs are the opportunity costs incurred for choosing to go to school, not other alternatives, for example, work.

The condition of income per capita in Central Java always increases every year. An increase in per capita income has a positive impact on the socio-economic welfare of the community, namely reducing the number of poor people. In percentage terms, poverty in Central Java decreased from $13.58 \%$ in 2014 to $13.01 \%$ in 2016. In 2017, the percentage of poor people declined again to $11,32 \%$.

Based on the estimation results show that the poverty rate has a negative and significant effect on mean years of school at a significant level of $5 \%$ in the Regencies and cities of Central Java Province. The value of the regression coefficient of the per capita income variable is -0,069514. This means that if the poverty level increases by $1 \%$, mean years of schooling will decrease by o,069514 years, assuming ceteris paribus.

This is in line with the research of Granado et al., (2007) which states that higher education requires higher costs as well so that the poor who do not have sufficient economic capacity to pay for their children's schooling can not send their children to a higher level. This study is also in line with research which states that children from poor households do not continue school because their parents cannot afford to pay for education costs, especially in developing countries. According to Muniroh (2012), for the poor, the cost of sending children to school is very high, both in terms of costs for schooling or loss of income that can be used for other purposes. Education in schools seems to be very expensive and difficult to reach. As a result, not a few of the poor families who choose to encourage their children to help shoulder the economic burden of the family by working and leave school.

\section{CONCLUSION}

Based on research above school dropout rate have a negative and unsignificant effect on mean years of schooling in the regencies and cities of Central Java Province. This is because even though the Central Java school dropout rate is ranked 3 rd from the provinces in Java, the continuing school rate is also high so that the number of students dropping out has not fully influenced the mean years of schooling in Central Java.

Child labor has a negative and significant effect on mean years of schooling in the regencies and cities of Central Java Province. children who have decided to work will have low motivation to continue their education. Child laborers are forced to work or choose to work because of the economic conditions of their families. This will affect the development of these children and can cause them to drop out of school and the learning process at school becomes ineffective.

The allocation of BOS funds has a positive but unsignificant effect on mean years of schooling in the regencies and cities of Central Java Province. The allocation of BOS funds has not been effective in increasing the mean years of schooling in Central Java. One 
of the causes of this is the problem of parents in meeting their educational needs which are not covered by BOS funds. BOS funds have been launched by the government to eliminate education costs, but have not supported the operational costs of school children such as books, uniforms, and transportation costs.

Per capita income has a negative and significant effect on mean years of schooling in the regencies and cities of Central Java Province. The higher the income per capita of society, the more they can send their children to school at the elementary and junior high school levels. This means an increase in per capita income will increase the mean year of schooling.

The poverty rate has a negative and significant effect on mean years of schooling in the regencies and cities of Central Java Province. Children from poor families do not go to school because their parents cannot afford to pay for education.

\section{REFERENCES}

Choiriyah, N. I., Linuwih, S., \& Salamah, M. (1990). Characteristics of Primary and Middle School Dropout Students in the North Surabaya Region. FPMIPA ITS, 1-10.

Dong, G. Y. R. (2014). Effects of Basic Education on Child Labor in Cibaduyut, Bandung. Parahyangan Catholic University.

Granado, A. del, Fengler, W., Ragatz, A., \& Yavuz, E. (2007). Investing in Indonesia's Education: Allocation, Equity, and Efficiency of Public Expenditures. MPRA Paper, (72288).
Gunawan, A. H. (2000). Educational Sociology. Jakarta: Rineka Cipta.

Hartoyo, S., \& Anggraeni, L. (2015). Determinants of Junior High School Participation Rates in West Java, 15 (1), 91-112.

International Labor Organization. (2009). Child Labor in Indonesia 2009.

Iskandar, S., \& Aziz, R. A. (2013). Working Children and Knowledge of Right to Education: A Study of Child Labor in Sabah, Malaysia. Canadian Center of Science and Education, 9.

Khanam, R. (2008). Child Labor and School Attendance: Evidence from Bangladesh. International Journal of Social Economics, 35 (1), 77-98.

Kharisma, B. (2013). Impact of School Operational Assistance Program (BOS) on School Drop Out Rate in Indonesia: Difference in Differences Analysis Impact of School Operational Assistance Program (BOS) on Dropout Rate in Indonesia: DID Analysis. Journal of Applied Quantitative Economics, 6 (May), 7-15.

Muniroh, S. M. (2012). Psychology of the Sustainability of Child Labor Schools in the Batik Sector. E-Journal Iain Pekalongan, $\quad 8 \quad$ (2). https://doi.org/10.28918/jupe.v8i2.68

Subri, M. (2003). Human Resource Economics in Development Perspective. Jakarta: PT Raja Grafindo Persada.

Suryadarma, D., Suryahadi, A., \& Sumarto, S. (2006). Causes of Low Secondary School Enrollment. The SMERU Research Institute, (August).

Todaro, M. P., \& Smith, S. C. (2006). Economic Development (9th ed.). Jakarta: Erlangga.

Todaro, M. P., \& Smith, S. C. (2011). Economic Development (11th ed.). Jakarta: Erlangga.

Vandenberg, P. (2009). Eliminating Child Labor. Jakarta: ILO.

Zahra, F. (2016). Relationship between Child Labor and Education Achievement and Household Welfare Levels. Bogor Agricultural Institute. 